\title{
TINGKAT PEMAHAMAN NELAYAN TERKAIT DENGAN KEBIJAKAN PELARANGAN PENANGKAPAN BENIH LOBSTER Panulirus spp.DI PALABUHANRATU
}

\author{
Fishermen's Understanding Level on Policy of Lobster Seeds Panulirus spp. Capture Prohibition in \\ Palabuhanratu \\ Oleh: \\ Furqan ${ }^{1 *}$, Tri Wiji Nurani ${ }^{2}$, Eko Sri Wiyono ${ }^{2}$, Deni Achmad Soeboer ${ }^{2}$ \\ ${ }^{1}$ Mahasiswa Program Pascasarjana Departemen PSP FPIK IPB \\ ${ }^{2}$ Staf Pengajar Departemen PSP FPIK IPB \\ *Korespondensi: furqan@apps.ipb.ac.id
}

\begin{abstract}
ABSTRAK
Lobster memiliki nilai ekonomis dan permintaan tinggi, baik untuk konsumsi maupun benih lobster (puerulus/ BL) untuk budidaya. Pemerintah membatasi ukuran penangkapan lobster Panulirus spp. dengan mengeluarkan PERMENKP No.1/2015 jo PERMENKP No.56/2016. Praktik penangkapan dan penyelundupan benih lobster di Palabuhanratu masih terjadi. Tujuan penelitian ini: 1)Menganalisis isi kebijakan PERMENKP No.1/2015, dan PERMENKP No.56/2016; 2)Mengukur tingkat pemahaman dan persepsi nelayan terhadap keberlanjutan sumberdaya lobster, dan sikap nelayan terhadap kebijakan. Penelitian ini dilakukan pada Bulan Juli-Agustus 2017 di Palabuhanratu Kabupaten Sukabumi. Data sekunder (dokumen kebijakan terkait perikanan lobster) dianalisis dengan content analysis, dan data primer (observasi, kuesioner dan wawancara) dianalisis dengan sequential explanatory design mengacu pada Creswell (2009). Analisis kebijakan menunjukkan ketentuan ukuran layak tangkap dalam kebijakan PERMENKP No.1/2015 jo PERMENKP No.56/2016 tidak melihat kondisi biologis dari masing-masing spesies. Kendala terkait implementasi kebijakan di wilayah Perairan Teluk Palabuhanratu yaitu kurangnya sosialisasi, dan sumberdaya kebijakan. Tingkat pengetahuan nelayan terhadap kebijakan sudah cukup, namun nelayan merasa bahwa penangkapan BL tidak mengganggu keberlanjutan lobster, sehingga nelayan menolak kebijakan tersebut.Sebaiknya kebijakan pemerintah mempertimbangkan kondisi di lapangan dengan informasi yang mendukung untuk keberlanjutan sumberdaya ikan, agar tepat sasaran dan memberi manfaat sosial ekonomi masa kini dan masa depan.
\end{abstract}

Kata kunci: benih lobster, kebijakan, persepsi nelayan.

\begin{abstract}
Lobster has economic value and high demand for consumption also aquaculture lobster seed (puerulus/BL). The government limits the Panulirus spp. size of lobster fishing by issuing PERMENKP No.1/2015 jo PERMENKP No.56/2016. BL fishing and smuggling in Palabuhanratu still occurs. Research purpose are: 1)Analyzing the policy content of PERMENKP No.1/2015, and PERMENKP No.56/2016; 2)Measuring fishermen's understanding and perception level on lobster resources sustainability, and fishermen's attitude to policy. This research conducted in July-August 2017 in Palabuhanratu Sukabumi Regency. Secondary data (lobster fisheries policy documents) were analyzed by content analysis, and primary data (observation, questionnaires and interview) were analyzed by sequential explanatory design . Policy analysis indicates the provision of appropriate catch size in lobster fisheries policy did not consider the each species biological conditions. Obstacles related to policy implementation in Palabuhanratu Bay Waters area were lack of socialization, and
\end{abstract}


policy resources. The fisherman's knowledge level of policy was sufficient, but they felt that $B L$ capture did not interfere with lobster sustainability, so they rejected it. It's advisable that government policies consider to field conditions with comprehensive information that support fisheries resources sustainability, to be proper purposes on target and provide socioeconomic benefits for present and the future.

Keywords: fisherman's perception, lobster seed, policy.

\section{PENDAHULUAN}

Lobster merupakan salah satu komoditi unggulan yang bernilai ekonomis tinggi, sehingga menjadi salah satu target tangkapan nelayan tradisional di Palabuhanratu.Seiring berjalannya waktu permintaan akan lobster tidak hanya untuk keperluan konsumsi saja, akan tetapi juga mencakup benih lobster (puerulus) yang digunakan untuk keperluan budidaya di Vietnam dengan harga yang tinggi. Harga yang ditawarkan yakni pada kisaran Rp14.000,00-Rp24.000,00/ekor pada Tahun 2014 (Witomo dan Nurlaili 2015). Tingginya permintaan dan harga tersebut dikhawatirkan akan mengancam keberlanjutan sumberdaya lobster Panulirus spp. karena semakin memicu upaya penangkapan.Oleh karenanya pemerintah perlu membatasi ukuran penangkapan lobster Panulirus spp. dengan mengeluarkan PERMENKP No.1/2015 tentang Penangkapan Lobster (Panulirus spp.), Kepiting (Scylla spp.), dan Rajungan (Portunus pelagicus spp.). Peraturan tersebut kemudian diganti dengan PERMENKP No.56/2016 tentang Larangan Penangkapan dan/atau Pengeluaran Lobster (Panulirus spp.), Kepiting (Scylla spp.), dan Rajungan (Portunus spp.) dari Wilayah Negara Republik Indonesia.

Pelarangan penangkapan dan atau pengeluaran lobster berdasarkan kebijakan tersebut pada implementasinya diharapkan mampu merubah persepsi dan meningkatkan kesadaran stakeholder perikanan lobster dalam menjaga keberlangsungan sumberdaya, khususnya nelayan lobster. Mengacu pada Wiyono (2009), bahwapersepsi nelayan terhadap sumberdaya perikanan merupakan proses pengorganisasian potensi daya yang dimiliki nelayan dalam menafsirkan pengelolaan sumberdaya perikanan di perairan, hal ini dimaksudkan untukdapat menciptakan perikanan lobster yang bertanggungjawab. Pada kenyataannya, sampai saat ini praktik penangkapan dan penyelundupan benih lobster di Palabuhanratu masih marak terjadi. Terlihat dengan banyaknya armada kapal congkreng yang awalnya melakukan penangkapan ikan (seperti ikan layur, lisong, dll) kinimemilih untuk alih target penangkapan ke benih lobster (BL).Pengamatan di lapangan juga menunjukkan bahwa jumlah pengumpul BLmasih banyak di berbagai perkampungan nelayan di Wilayah Perairan Teluk Palabuhanratu. Kegiatan penyelendupan BL dari Palabuhanratu juga berlangsung hampir setiap hari dengan jalur yang bervariasi, baik melalui jalur darat, laut dan udara dengan tujuan akhir ke negara Singapura ataupun langsung ke Vietnam. Pertanyaan mendasar yang ingin dikemukakan oleh peneliti yakni seperti apa isi kebijakan PERMENKP No.1/2015 dan PERMENKP No.56/2016? Seperti apatingkat pemahaman dan persepsi nelayan terhadap nelayan terhadap keberlanjutan sumberdaya lobster, dan sikap nelayan terhadap kebijakan PERMENKP No.56/2016.

Berdasarkan pemaparan di atas, maka tujuan yang ingin dicapai dalam penelitian ini yakni: 1)Menganalisis isi kebijakanPERMENKP No.1/2015, dan PERMENKP No.56/2016 2) Mengukur tingkat pemahaman dan persepsi nelayan terhadap keberlanjutan sumberdaya lobster, dan sikap nelayan terhadap kebijakan PERMENKP No.56/2016.

\section{METODE PENELITIAN}


Penelitian ini dilakukan pada Bulan Juli-Agustus 2017. Pengambilan data dilakukan di Palabuhanratu Kabupaten Sukabumi.Jenis dan Sumber Data yang digunakan meliputi:

1. Analisis isi kebijakan

Penelitian tentang isi kebijakan dilakukan dengan menggunakan dokumen kebijakan terkait perikanan lobster. Dokumen yang dimaksud yakni PERMENKP No.1/2015 serta PERMENKP No.56/2016. Data lain yang digunakan dalam analisis isi kebijakan yakni wawancara kepada stakeholder perikanan lobster, dan observasi di lapangan. Stakeholder perikanan lobster yang diwawancarai meliputi target sasaran kebijakan (nelayan dan pengumpul benih lobster), serta implementor kebijakan (Satuan PSDKP Sukabumi).

2. Tingkat pemahaman dan persepsi nelayan terhadap keberlanjutan sumberdaya lobster, dan PERMENKP No.1/2015 jo PERMENKP No.56/2016.

Data yang digunakan dalam kajian ini berupa data primer dengan menggunakan kuesioner, serta wawancara dan observasi langsung. Pengambilan data dengan kuesioner dilakukan secara purposive sampling kepada 30 nelayan penangkap benih lobster. Kuesioner yang digunakan menggunakan skala Likert 1-4, dimanaskala Likert yang digunakan yakni nilai 1 menunjukkan nilai paling rendah (sangat tidak setuju), sedangkan nilai 4 menunjukkan nilai paling tinggi (sangat setuju). Pertanyaan-pertanyaan yang diajukan meliputi tingkat pengetahuan dan jumlah sosialisasi kebijakan yang diterima nelayan, serta persepsi nelayan terhadap dampak penangkapan benih lobster terhadap keberlanjutan sumberdaya. Pertanyaan lain yang diajukan yakni membandingkan berbagai aspek dari penangkapan benih lobster yang dibandingkan dengan penangkapan ikan. Aspek tersebut meliputi kemudahan teknis penangkapan, besaran keuntungan, dan preferensi penangkapan benih lobster. Wawancara mendalam dilakukan kepada informan yang meliputi pihak pengumpul, Satuan PSDKP Sukabumi. Informan-informan tersebut diminta untuk menjelaskan kondisi di lapangan terkait dengan aktivitas penangkapan benih lobster. Stakeholder lain yang diwawancarai yakni DKP Kab. Sukabumi, dan Kepolisian Resor Sukabumi.

Analisis data yang digunakan dalam penelitian ini yakni:

1. Analisis isi kebijakan

Analisis isi (content analysis) kebijakanPERMENKP No.1/2015 jo PERMENKP No.56/2016 dilakukan dengan mengacu pada Purwaka (2002), dimana analisis kebijakan dilakukan dengan menilai peraturan perundangan yang ada berdasarkan latar belakang, mandat, implementasi, dan kendala atau kelemahan yang dihadapi di lapangan dalam penerapan peraturan perundangan. Hasil analisis tersebut kemudian ditabulasikan ke dalam bentuk tabel dan dibahas secara deskriptif.

2. Analisis tingkat pemahaman dan persepsi nelayan

Data yang diperoleh dari kuesioner terkait persepsi nelayan dianlisis dengan menggunakan nilai rata-rata dari masing-masing pertanyaan yang kemudian dibuat ke dalam bentuk diagram batang. Data dari masing-masing pertanyaan juga dihitung nilai persentasenya serta dimuat ke dalam bentuk diagram kue (pie chart). Hasil penelitian tersebut kemudian dianalisis secara deskriptif dan dikombinasikan dengan hasil wawancara mendalam dengan stakeholder, sehingga dalam penelitian terkait persepsi nelayanmerupakan kombinasi data kuantitatif dan kualitatif dengan jenis sequential explanatory design yang mengacu pada Creswell (2009).

\section{HASIL DAN PEMBAHASAN}

\section{Analisis isi kebijakan}

Hasil analisis isi kebijakan PERMENKP No.1/2015 jo PERMENKP No.56/2016 terkait perikanan lobster dapat dilihat pada Tabel 1. 
Tabel 1 Analisis isi kebijakan PERMENKP No.1/2015 jo PERMENKP No.56/2016 terkait perikanan lobster dan implementasi serta kendalanya di Palabuhanratu.

\section{PERMENKP No. 1/2015}

\begin{tabular}{l}
\hline \multicolumn{1}{c}{ Latar Belakang } \\
\hline \\
\end{tabular}

\begin{tabular}{l}
\multicolumn{1}{c}{ Mandat } \\
\multicolumn{1}{c}{ Pasal 2} \\
Setiap orang dilarang \\
melakukan penangkapan \\
Lobster (Panulirus spp.) \\
dalam kondisi bertelur.
\end{tabular}

- Sosialisasi kepada $\quad$ - Penangkapan terhadap lobster
pengumpul lokal dalam keadaan bertelur masih dan eksportir, serta terjadi karena adanya permintaan pengawasan pada dari pasar lokal, ataupun dalam kondisi bertelur. karantina hewan pengumpul menunggu hingga dan ikan bandara. lobster selesai menetaskan telur untuk kemudian diekspor.

\begin{tabular}{l} 
Pasal 3 (1a) \\
Penangkapan Lobster \\
(Panulirus spp.) dapat \\
dilakukan dengan ukuran \\
panjang karapas $>8 \mathrm{~cm}$ (di \\
atas delapan sentimeter) \\
\multicolumn{1}{c}{ Pasal 4 (a) } \\
Setiap orang yang \\
menangkap Lobster \\
(Panulirus spp.) wajib \\
melepaskan Lobster \\
(Panulirus spp.) yang \\
dalam kondisi bertelur \\
(Pasal 2) dan/ atau dengan \\
ukuran tidak sesuai dengan \\
kriteria pada Pasal 3 (1a) \\
bila dalam keadaan hidup.
\end{tabular}

- Sosialisasi kepada - Secara bahasa hukum, tidak nelayan, disebutkan dengan jelas kepada pengumpul lokal, siapa pasal 3 (1a) ditujukan; dan eksportir, serta - Tidak disebutkan dengan jelas pengawasan pada implementor untuk pengawasan karantina hewan di lapangan; dan ikan bandara; - Penangkapan lobster konsumsi - Upaya penegakan hukum berupa penangkapan terhadap pengumpul dan - Adanya permintaan untuk pasar penyelundup benih dalam negeri untuk lobster lobster dengan ukuran konsumsi dengan panjang barang bukti 3.526 karapas kurang dari $8 \mathrm{~cm}$, Benih Lobster. sehingga penangkapan dan penjualan masih terjadi;

- Permintaan untuk kegiatan penyelundupan benih lobster masih terjadi, dan harga yang ditawarkan justru mengalami peningkatan;

- Kondisi sosial-ekonomi masyarakat dan nelayan tidak mendukung implementasi kebijakan

\begin{tabular}{|c|c|c|}
\hline $\begin{array}{l}\quad \text { Pasal } 4 \text { (b) } \\
\text { Setiap orang yang } \\
\text { menangkap Lobster } \\
\text { (Panulirus spp.) wajib } \\
\text { melakukan pencatatan } \\
\text { Lobster (Panulirus spp.) } \\
\text { yang dalam kondisi } \\
\text { bertelur (Pasal 2) dan/ atau } \\
\text { dengan ukuran tidak sesuai } \\
\text { dengan kriteria pada Pasal } \\
3 \text { (1a)yang tertangkap } \\
\text { dalam keadaan mati dan } \\
\text { melaporkan kepada } \\
\text { Direktur Jenderal melalui } \\
\text { kepala pelabuhan } \\
\text { pangkalan sebagaimana } \\
\text { tercantum dalam Surat } \\
\text { Izin Penangkapan Ikan }\end{array}$ & $\begin{array}{l}\text { - Sosialisasi } \\
\text { dilakukan oleh } \\
\text { pihak PPNP } \\
\text { melalui spanduk } \\
\text { dan himbauan di } \\
\text { Kantor syahbandar } \\
\text { perikanan }\end{array}$ & $\begin{array}{l}\text { - Kegiatan penangkapan lobster } \\
\text { ukuran konsumsi dilakukan oleh } \\
\text { nelayan tradisional dengan } \\
\text { menggunakan ban dalam bekas } \\
\text { mobil, sehingga tidak melibatkan } \\
\text { pihak PPNP; } \\
\text { - Penangkapan benih lobster } \\
\text { dilakukan dengan bagan apung, } \\
\text { dan kapal congkreng dengan } \\
\text { ukuran panjang 7-9 meter, dan } \\
\text { menjadi wewenang pihak } \\
\text { Provinsi Jawa Barat, }\end{array}$ \\
\hline
\end{tabular}


Lanjutan Tabel 1. Analisis isi kebijakan PERMENKP No.1/2015 jo PERMENKP No.56/2016 terkait perikanan lobster dan implementasi serta kendalanya di Palabuhanratu.

\begin{tabular}{|c|c|c|c|}
\hline \multicolumn{4}{|l|}{ PERMENKP No. 56/2016 } \\
\hline Latar Belakang & Mandat & Implementasi & Kendala \\
\hline $\begin{array}{l}\text { Bahwa dalam rangka } \\
\text { melaksanakan ketentuan Pasal } \\
7 \text { ayat (1) huruf q dan huruf t } \\
\text { Undang-Undang Nomor } 31 \\
\text { Tahun } 2004 \text { tentang } \\
\text { Perikanan, sebagaimana telah } \\
\text { diubah dengan Undang- } \\
\text { Undang Nomor } 45 \text { Tahun } 2009 \\
\text { tentang Perubahan atas } \\
\text { Undang-Undang Nomor } 31 \\
\text { Tahun 2004 tentang } \\
\text { Perikanan, perlu mengatur } \\
\text { larangan penangkapan dan } \\
\text { pengeluaran Lobster } \\
\text { (Panulirus spp.) dariWilayah } \\
\text { Negara Republik Indonesia; } \\
\text { Bahwa dalam rangka menjaga } \\
\text { keberadaan dan ketersediaan } \\
\text { populasi sumber daya Lobster } \\
\text { (Panulirus spp.) perlu } \\
\text { mengatur kembali } \\
\text { penangkapan Lobster } \\
\text { (Panulirus spp.), sebagaimana } \\
\text { diatur dalam Peraturan } \\
\text { Menteri Kelautan dan } \\
\text { Perikanan Nomor 1/PERMEN- } \\
\text { KP/2015; }\end{array}$ & $\begin{array}{l}\text { Pasal } 2 \\
\text { Penangkapan dan/atau } \\
\text { Pengeluaran Lobster } \\
\text { (Panulirus spp.), dengan } \\
\text { Harmonized System Code } \\
\text { 0306.21.10.00 atau } \\
\text { 0306.21.20.00, dari } \\
\text { wilayah Negara Republik } \\
\text { Indonesia hanya dapat } \\
\text { dilakukan dengan } \\
\text { ketentuan: } \\
\text { 1.tidak dalam kondisi } \\
\text { bertelur; dan } \\
\text { '. ukuran panjang karapas } \\
\text { diatas } 8 \text { (delapan) cm atau } \\
\text { berat diatas } 200 \text { (dua } \\
\text { ratus) gram per ekor. } \\
\text { Pasal 7 (1) } \\
\text { Setiap orang dilarang } \\
\text { menjual benih lobster } \\
\text { untuk budidaya. }\end{array}$ & $\begin{array}{l}\text { - Sosialisasi } \\
\text { kepada nelayan } \\
\text { BL, pengumpul } \\
\text { BL dan } \\
\text { eksportir, serta } \\
\text { pengawasan } \\
\text { pada karantina } \\
\text { hewan dan ikan } \\
\text { bandara } \\
\text { - Upaya } \\
\text { penegakan } \\
\text { hukum berupa } \\
\text { penangkapan } \\
\text { terhadap } \\
\text { pengumpul dan } \\
\text { penyelundup } \\
\text { benih lobster }\end{array}$ & $\begin{array}{l}\text { - Secara bahasa hukum (Pasal 2) } \\
\text { tidak disebutkan kepada siapa } \\
\text { aturan tersebut ditujukan } \\
\text { - Penangkapan terhadap lobster } \\
\text { dalam keadaan bertelur masih } \\
\text { terjadi karena adanya } \\
\text { permintaan dari pasar lokal } \\
\text { ataupun pengumpul } \\
\text { menunggu hingga lobster } \\
\text { selesai menetaskan telur } \\
\text { untuk kemudian diekspor. } \\
\text { - Penangkapan lobster } \\
\text { konsumsi dengan panjang } \\
\text { karapas diatas } 8 \text { (delapan) cm } \\
\text { atau berat diatas } 200 \text { (dua } \\
\text { ratus) gram per ekor sulit } \\
\text { dilakukan oleh nelayan } \\
\text { tradisional dengan alat } \\
\text { tangkap jaring bloon; } \\
\text { - Permintaan untuk kegiatan } \\
\text { penyelundupan benih lobster } \\
\text { masih terjadi, dan harga yang } \\
\text { ditawarkan justru mengalami } \\
\text { peningkatan; } \\
\text { - Kondisi sosial-ekonomi } \\
\text { masyarakat dan nelayan tidak } \\
\text { mendukung implementasi } \\
\text { kebijakan. }\end{array}$ \\
\hline $\begin{array}{l}\text { Bahwa berdasarkan } \\
\text { pertimbangan sebagaimana } \\
\text { dimaksud pada huruf a dan } \\
\text { huruf b, perlu menetapkan } \\
\text { Peraturan Menteri Kelautan } \\
\text { dan Perikanan tentang } \\
\text { Larangan Penangkapan dan } \\
\text { Pengeluaran Lobster } \\
\text { (Panulirus spp.) dari Wilayah } \\
\text { Negara Republik Indonesia. }\end{array}$ & $\begin{array}{l}\text { Pasal 7 (2) } \\
\text { Setiap orang yang } \\
\text { menangkap Lobster } \\
\text { (Panulirus spp.) wajib: } \\
\text { melepaskan Lobster } \\
\text { (Panulirus spp.) yang } \\
\text { tidak sesuai dengan } \\
\text { ketentuan sebagaimana } \\
\text { dimaksud dalam Pasal } 2 \\
\text { jika dalam keadaan hidup } \\
\text { melakukan pencatatan } \\
\text { Lobster (Panulirus spp.) } \\
\text { yang tidak sesuai dengan } \\
\text { ketentuan sebagaimana } \\
\text { dimaksud dalam Pasal } 2 \\
\text { yang tertangkap dalam } \\
\text { keadaan mati dan } \\
\text { melaporkan kepada } \\
\text { Direktur Jenderal melalui } \\
\text { kepala pelabuhan } \\
\text { pangkalan sebagaimana } \\
\text { tercantum dalam Surat } \\
\text { Izin Penangkapan Ikan. }\end{array}$ & $\begin{array}{l}\text { - Sosialisasi } \\
\text { dilakukan oleh } \\
\text { pihak PPNP } \\
\text { melalui } \\
\text { spanduk dan } \\
\text { himbauan di } \\
\text { Kantor } \\
\text { Syahbandar } \\
\text { Perikanan. }\end{array}$ & $\begin{array}{l}\text { Kegiatan penangkapan lobster } \\
\text { ukuran konsumsi dilakukan } \\
\text { oleh nelayan tradisional } \\
\text { dengan menggunakan ban } \\
\text { dalam bekas mobil, sehingga } \\
\text { tanpa melibatkan pihak } \\
\text { PPNP; }\end{array}$ \\
\hline
\end{tabular}


Lanjutan Tabel 1. Analisis isi kebijakan PERMENKP No.1/2015 jo PERMENKP No.56/2016 terkait perikanan lobster dan implementasi serta kendalanya di Palabuhanratu.

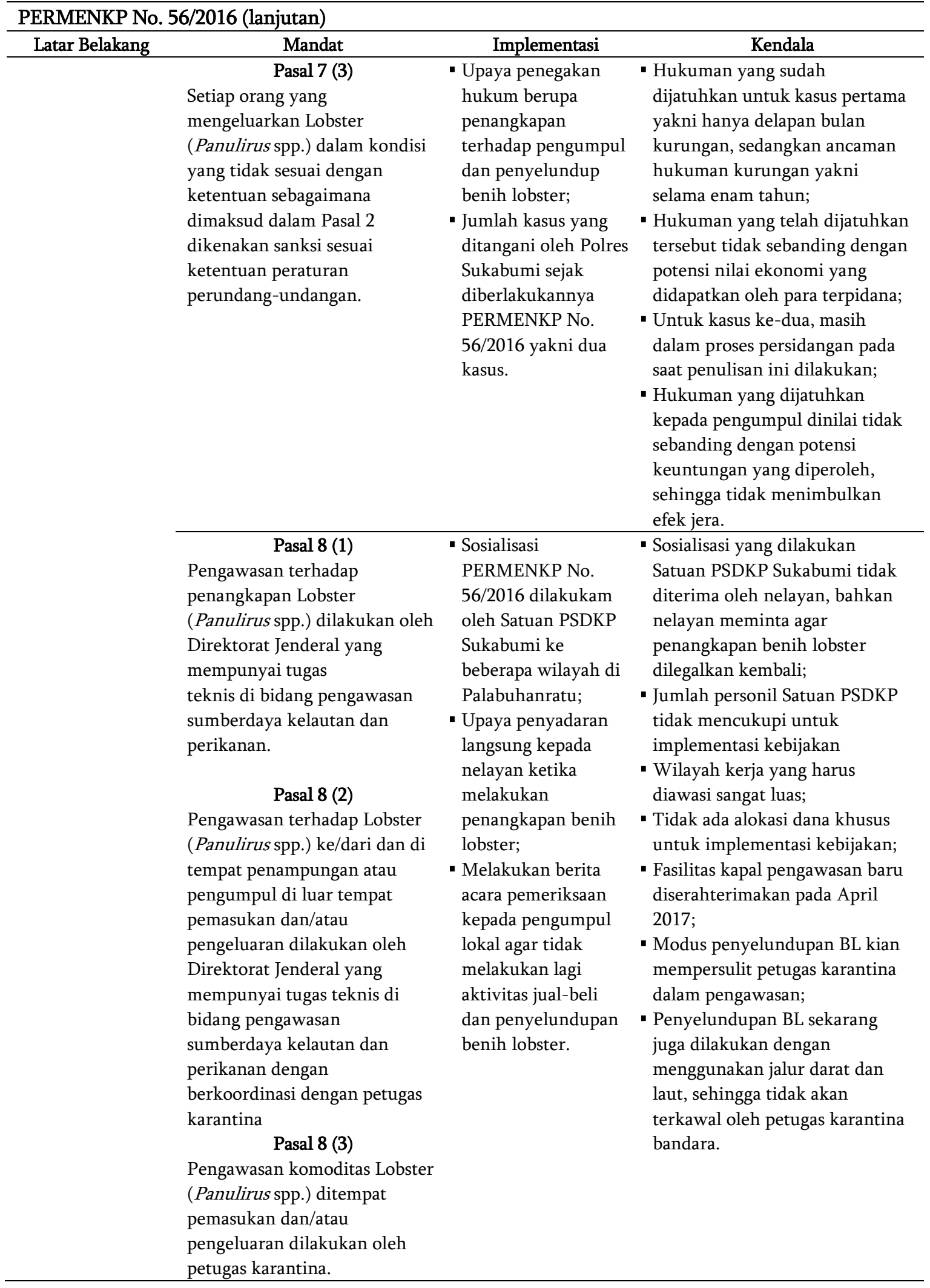


Pertimbangan utama yang menjadi latar belakang dari hadirnya PERMENKP No.1/2015 jo PERMENKP No.56/2016, yakni kekhawatiran akan berkurangnya stok sumberdaya lobster dan terindikasi dengan adanya trend penurunan volume ekspor lobster konsumsi dari Indonesia pada rentang tahun 2012-2014. Tercatat volume ekspor lobster pada Tahun 2012 mencapai 5.300 ton senilai 50,6 juta dolar AS, dan pada tahun 2013 mengalami penurunan dengan volume ekspor mencapai 5.150 ton senilai 69,9 juta dolar AS. Penurunan volume ekspor ini terus berlangsung hingga pada Tahun 2014 total volume ekspor turun menjadi 3.430 ton dengan nilai 42,8 juta dolar AS (Wij dan Hen 2015). Phillips dan Smith (2006) menyatakan bahwa semua jenis Lobster Panulirus spp dikhawatirkan telah tereksploitasi penuh dikarenakan kegiatan penangkapan yang agresif di alam, tak terkecuali di Indonesia seperti yang dikemukakan oleh Junaidi et al (2010) dimana meningkatnya pasar domestik maupun ekspor, menyebabkan penangkapan komoditas lobster semakin intensif. Akan tetapi semua pertimbangan dan penelitian tersebut bertolak belakang dengan yang dikemukakan oleh para peneliti dari Balai Riset Kelautan dan Perikanan yang ditulis oleh Suman et al. (2014), dimana kegiatan penangkapan lobster di wilayah WPP-RI 573 belum melebihi potensi lestarinya. Hasil penelitian lain memprediksikan bahwa tingkat kematian lobster Panulirus spp. di alam mencapai $88-99 \%$, serta hanya sedikit dampak dari pengambilan BL P. cygnus di alam untuk keperluan budidaya karena tingginya tingkat kematian alami (Herrnkind dan Butler 1994; Phillips et al. 2003). Childress dan Jurry (2006) juga menambahkan bahwa dengan banyaknya penelitian dan penemuan terkait lobster, para peneliti masih belum bisa memprediksikan dengan pasti dampak dari kegiatan penangkapan lobster sekarang terhadap keberlanjutan dari lobster itu sendiri. Salah satu alasan utama dari Childress dan Jurry (2006) yakni lobster memiliki strategi tingkah laku yang sangat bervariasi dan menjadi pembatas peneliti dalam membuat asumsi model pertumbuhan populasi lobster.

\section{Tingkat pemahaman dan persepsi nelayan benih lobster terhadap kebijakan}

Pengetahuan dan persepsi nelayan terhadap kebijakan dalam hal ini terkait keberlanjutan sumberdaya lobster Panulirus spp. merupakan output akhir yang ingin dicapai dalam implementasi kebijakan. Output yang diharapkan tentunya berupa penerimaan kebijakan dan timbulnya kesadaran nelayan akan arti pentingnya keberlanjutan sumberdaya lobster Panulirus spp. itu sendiri. Gambar 1 merupakan nilai rata-rata hasil penelitian terkait persepsi nelayan BL terhadap kebijakan, dimana rata-rata jawaban nelayan terkait pengetahuan adanya pelarangan penangkapan BL sebesar 3,2. Nilai tersebut menunjukkan bahwa nelayan hanya mengetahui adanya pelarangan tanpa mengetahui tujuan dari pelarangan, yakni untuk menjaga keberlanjutan sumberdaya lobster. Pengetahuan ini bertolak belakang dengan jumlah sosialisasi yang diterima, dimana dominan nelayan menuturkan bahwa mereka tidak pernah mendapat sosialisasi secara langsung dan pelarangan tersebut diperoleh dari sesama nelayan saja. Hasil ini ditunjukkan dengan rata-rata nilai sosialisasi yang diterima sebesar 1,3. Hasil wawancara dengan pihak DKP Kabupaten Sukabumi membenarkan bahwa sosialisasi yang dilakukan kepada perwakilan Kelompok Usaha Bersama (KUB) dan pada semua titik TPI, akan tetapi upaya tersebut nampaknya tidak berhasil menyampaikan tujuan dari pelarangan penangkapan BL. Akibat kurangnya sosialisasi yang diterima oleh nelayan tersebut, maka hasil wawancara menunjukkan bahwa semua nelayan merasa bahwa kegiatan penangkapan BL tidak mengancam keberlanjutan sumberdaya lobster (Nilai rata-rata 4).

Lebih lanjut, ketika diminta untuk membandingkan dengan kegiatan penangkapan ikan, maka semua nelayan menilai bahwa penangkapan BL sangat lebih mudah secara teknis penangkapan. Hasil tersebut ditunjukkan pada Gambar 1 dimana secara keselurahan responden memberi nilai 4. Hasil yang sama juga diperoleh dari keuntungan yang diperoleh, dimana semua nelayan menilai bahwa penangkapan BL sangat menguntungkan (Nilai 4). Pertanyaan terakhir yang diajukan dalam penelitian yakni dukungan nelayan terhadap kebijakan, diperoleh hasil bahwa rata-rata nelayan menjawab 1,1 sehingga diperoleh bahwa dominan nelayan menjawab sangat tidak mendukung 
kebijakan PERMENKP No.56/2016. Guna lebih rinci, maka masing-masing komponen pertanyaan untuk mengukur tingkat pemahaman dan persepsi nelayan dibahas satu per satu.

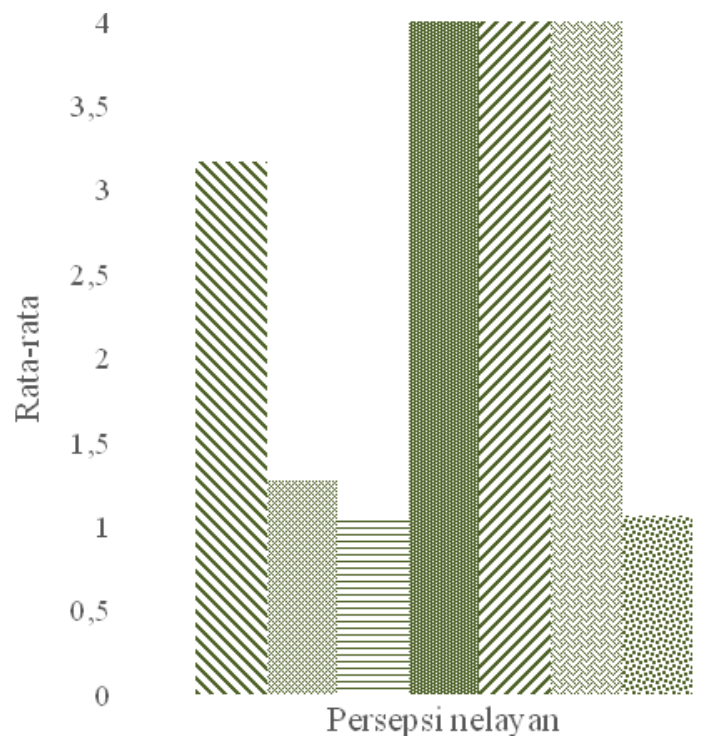

\author{
NMengetahui kebijakan \\ Sosialisasi yg diterima \\ $\equiv$ Dampak penangkapan BL \\ terha dap Keberlanjutan lobster \\ 驩 Kemudahan teknis penangkapan \\ BL dibandingkan ikan \\ \%. Keuntungan menangkap BL \\ dibandingkan ikan \\ 衿Preferensi antara menangkap \\ ikan dibandingkan ikan \\ Dukungan terhadap kebijakan
}

Gambar 1 Rata-rata nilai persepsi nelayan terkait kebijakan PERMENKP No.56/2016

\title{
Pengetahuan nelayan tentang pelarangan penangkapan benih lobster
}

Pengetahuan nelayan akan adanya pelarangan penangkapan dan penjualan dinilai sudah cukup memenuhi, terlihat pada Gambar 2 sebanyak 83\% nelayan menjawab mengetahui adanya pelarangan tersebut. Sebanyak $17 \%$ nelayan menjawab sangat mengetahui kebijakan tersebut dengan menjelaskan tujuan pelarangan untuk menjaga keberlanjutan sumberdaya lobster. Kondisi di lapangan menunjukkan bahwa nelayan tetap melakukan penangkapan BL meskipun sudah mengetahui adanya pelarangan. Hal ini disebabkankelangkaan ikan layur yang dulunya menjadi target utama nelayan congkreng.

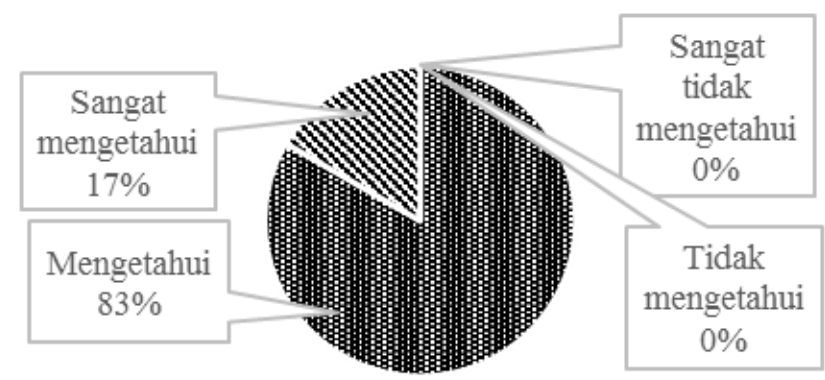

Gambar 2 Distribusi responden berdasarkan pengetahuan terhadap kebijakan.

\section{Sosialisasi kebijakan yang diterima nelayan}

Hasil penelitianmenunjukkan bahwa sebanyak 73\% nelayan BL mengaku tidak pernah mendapat sosialisasi secara langsung dari implementor kebijakan dan instansi terkait. Sebanyak 27\% nelayan mendapat sosialisasi secara langsung dengan intensitas 1-2 kali dalam satu tahunnya (Gambar 3). Penyebabnya yakni kegiatan sosialisasi yang dilakukan oleh DKP Kab. Sukabumi dan pihak Karantina Provinsi Jabar hanya diwakili oleh perwakilan Kelompok Usaha Bersama (KUB). Sosialisasi tersebut dilakukan di Kantor DKP Cimaja dan semua titik TPI. 


\section{Dampak penangkapan benih lobster terhadap keberlanjutan sumberdaya}

Berdasarkan informasi dan hasil analisis, maka secara umum dapat disimpulkan bahwa nelayan mengetahui informasi adanya kebijakan pelarangan penangkapan BL, akan tetapi intensitas dan penyampaian tersebut seharusnya dilakuan secara langsung dan menyeluruh kepada nelayan. Akibat dari kurangnya intensitas sosialisasi PERMENKP No.56/2016 yang diberikan langsung kepada nelayan BL, maka sebanyak 97\% responden merasa bahwa kegiatan penangkapan BL sangat tidak mengganggu keberlanjutan sumberdaya lobster. Hanya sebesar 3\% responden merasa penangkapan BL tidak mengganggu keberlanjutan sumberdaya lobster (Gambar 4). Persepsi nelayan yang demikian, menyebabkan kegiatan penangkapan BL berlangsung hampir setiap hari bahkan ketika kondisi terang bulan, meskipun jumlah BL yang diperoleh tidak sebanyak pada saat bulan gelap.

\section{Teknis penangkapan benih losbter}

Teknis penangkapan BL yang dilakukan di wilayah Teluk Palabuhanratu dilakukan oleh nelayan pada malam hari dengan menggunakan kapal congkreng dan bagan apung dengan menggunakan bantuan lampu dengan sumber listrik yang berasal dari genset. Alat tangkap yang digunakan oleh nelayan kapal congkrengyakni dengan menggunakan klasifikasi alat tangkap berupa trap dengan bahan dasar jaring monofilament jenis $\mathrm{PE}$ dengan mesh size $10 \mathrm{~mm}$ yang dimodifikasi. Jenis modifikasi alat yakni berupa rumbai-rumbai yang diikat dengan tali berupa lingkaran, sedangkan bentuk modifikasi lain yang dilakukan yakni dengan membuat jaring menjuntai. Secara umum durasi setting alat tangkap yang dilakukan berkisar 3-4 jam, dan jumlah hauling yang dilakukan dalam satu kali trip berkisar 3-4 kali. Kondisi teknis penangkapan yang demikian mudah bagi nelayan, serta banyaknya jumlah hasil tangkapan BL (bisa mencapai 500 ekor/ trip), membuat nelayan 100\% menjawab secara teknis penangkapan BL sangat jauh lebih mudah bila dibandingkan dengan menangkap ikan (Gambar 5).

\section{Pendapatan nelayan dari penangkapan benih losbter}

Faktor lain yang menjadi fokus penelitan yakni tingkat pendapatan nelayan dari kegiatan penangkapan benih lobster. Hasil penelitian menunjukkan bahwa harga jual BL bergantung pada jenis bibit lobster, dimana pada Tahun 2017 di tingkat nelayan berkisar Rp. 2000-10.000/ ekor untuk jenis lobster P. homarus, sedangkanjenis lobster P. ornatus berkisar Rp. 30.000-45.000/ ekor. Informasi lain yang diperoleh bahwa pada kegiatan perdagangan dan penyelundupan BL ini sepenuhnya dikontrol oleh para penyelundup besar. Akan tetapi bila dilihat dari besarnya potensi pendapatan nelayan, persoalan harga tidaklah terlalu menjadi kendala mengingat kecilnya biaya operasional yang dikeluarkan untuk setiap trip penangkapan yang berkisar 100.000-200.000 rupiah. Kondisi ini dikemukakan oleh nelayan sekaligus pemilik dua kapal congkreng yang mengaku bahwa mampu mendapatkan keuntungan hingga Rp. 70.000 .000 selama dua bulan. Nelayan bagan apung juga mengungkapkan hal serupa, bahwa penghasilan yang diperoleh ketika musim puncak penangkapan BL yakni Rp. 2.000.000 dalam satu malam. Hasil analisis mengungkapkan bahwa sebanyak $100 \%$ responden nelayan yang biasanya melakukan penangkapan ikan layur dan kini beralih target tangkapan ke BL, merasa bahwa penangkapan BL sangat menguntungkan (Gambar 6).

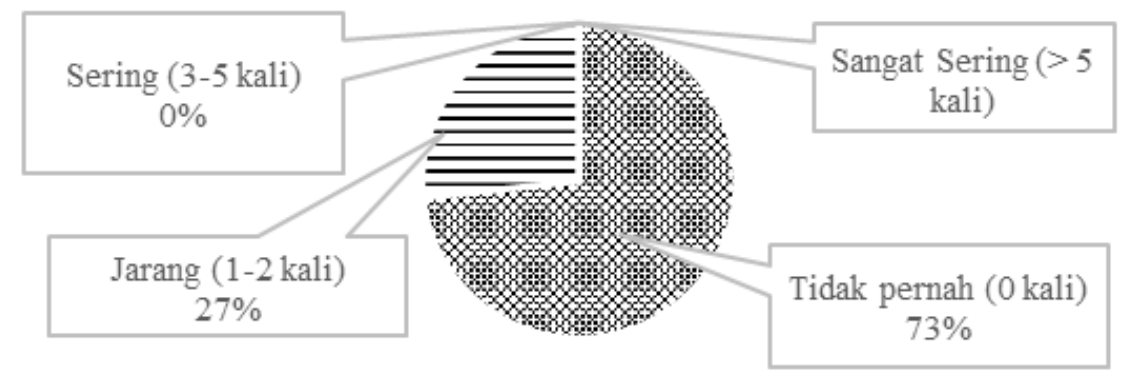

Gambar 3 Distribusi responden berdasarkan jumlah sosialisasi yang diterima per tahun 


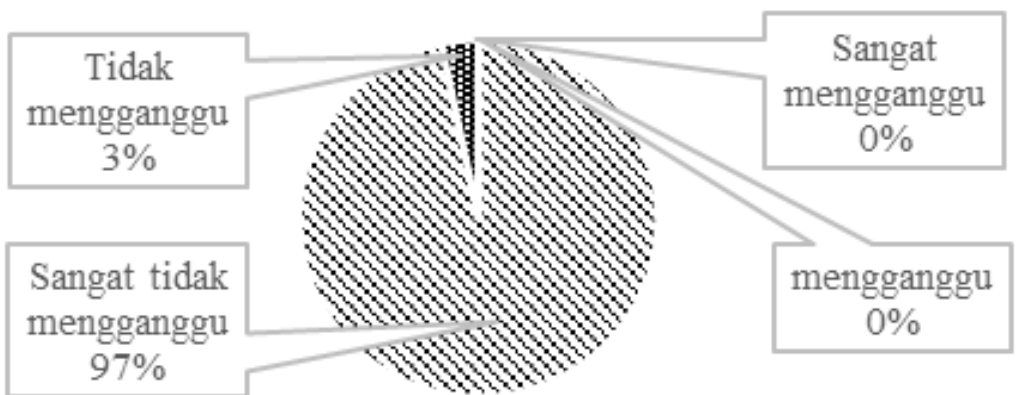

Gambar 4 Distribusi responden berdasarkan dampak penangkapan benih lobster terhadap keberlanjutan sumberdaya lobster

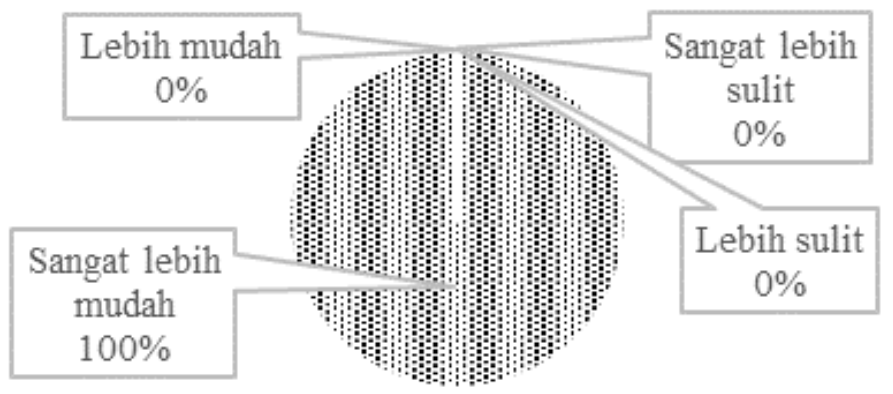

Gambar 5 Distribusi responden berdasarkan tingkat kemudahan secara teknis antara penangkapan benih lobster dan penangkapan ikan

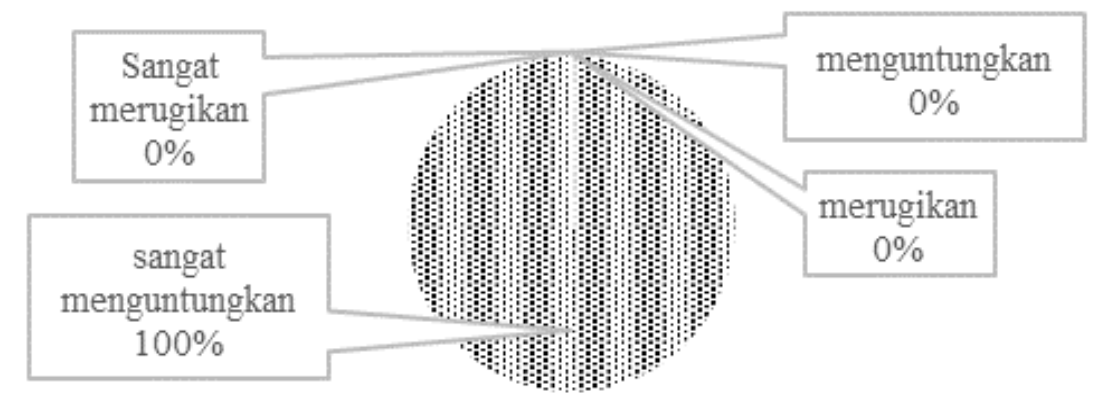

Gambar 6 Distribusi responden berdasarkan hasil pendapatan penangkapan BL dibandingkan dengan menangkap ikan

\section{Preferensi nelayan menangkap benih losbter}

Hasil analisis menunjukkan bahwa 100\% nelayan sangat memilih melakukan penangkapan lobster bila dibandingkan dengan menangkap ikan (Gambar 7). Kondisi ini dikarenakan alasan bahwa menangkap lobster secara teknis lebih mudah, lebih menguntungkan, dan hanya membutuhkan biaya operasional yang lebih murah. Pertimbangan lain nelayan bahwa dalam melakukan pemasaran BL hasil tangkapan tidak sulit dan tidak membutuhkan biaya tambahan lain.

\section{Dukungan nelayan benih lobster terhadap kebijakan pemerintah}

Fokus kajian selanjutnya yakni dukungan dari nelayan terhadap kebijakan PERMENKP No.1/2015 jo PERMENKP No.56/2016. Hasil penelitian menunjukkan bahwa sebanyak 93\% nelayan sangat tidak mendukung adanya pelarangan penangkapan BL, dan sebanyak 7\% nelayan menjawab tidak mendukung (Gambar 8). Kondisi ini dimungkinkan karena dimulai dengan tingkat sosialisasi yang kurang sehingga nelayan tidak mendapat informasi yang utuh tentang tujuan dari kebijakan tersebut. Permasalahan lain yakni tidak adanya solusi lain dengan kurangnya minimnya hasil 
tangkapan ikan, bahkan kondisi real di lapangan menunjukkan bahwa kegiatan penangkapan BL menjadi satu-satunya solusi bagi nelayan dalam memenuhi kebutuhan hidup.

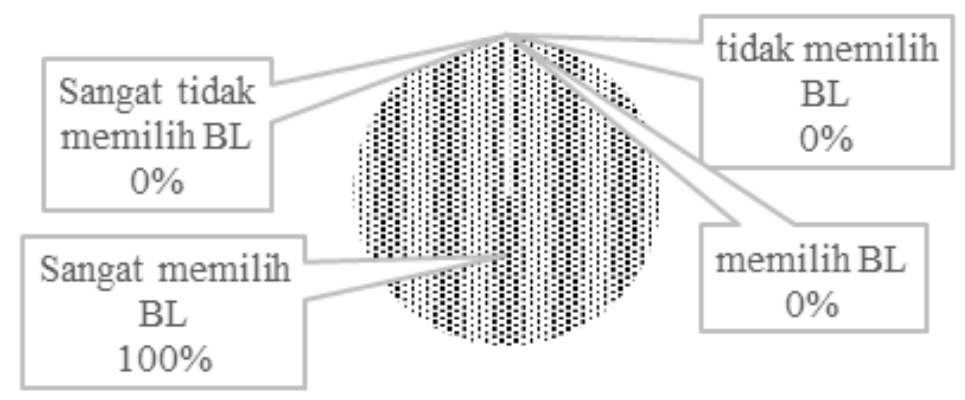

Gambar 7 Distribusi responden berdasarkan prefensi menangkap benih lobster dibandingkan dengan menangkap ikan

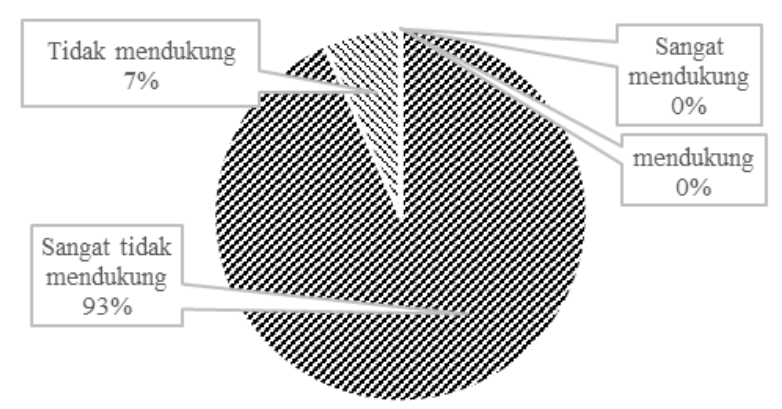

Gambar 8 Distribusi responden berdasarkan tingkat dukungan terhadap kebijakan

\section{KESIMPULAN DAN SARAN}

\section{Kesimpulan}

1. Hasil analisis isi kebijakan menunjukkan bahwa ketentuan ukuran layak tangkap dalam kebijakan PERMENKP No.1/2015 jo PERMENKP No.56/2016 sejatinya tidak melihat kondisi biologis dari masing-masing spesies Panulirus spp., serta belum adanya kajian yang bersifat komprehensif terkait status sumberdaya lobster baik untuk ukuran konsumsi maupun benih lobster. Kendala-kendala yang dihadapi terkait implementasi kebijakan di wilayah Perairan Teluk Palabuhanratu dimulai dengan kurangnya sosialisasi serta kurangnya sumberdaya kebijakan, baik itu jumlah SDM implementor dan kurangnya dukungan dana untuk mengawal kebijakan;

2. Terkait persepsi nelayan, secara umum tingkat pengetahuan nelayan terhadap kebijakan sudah cukup. Namun demikiannelayan merasa bahwa penangkapan BL tidak mengganggu keberlanjutan lobster, sehingga nelayan menolak kebijakan PERMENKP No.1/2015 jo PERMENKP No.56/2016.

\section{Saran}

Pemerintah dalam membuat kebijakan diharapkan mempertimbangkan kondisi di lapangan dengan informasi yang lengkap, sehingga kebijakan akan tepat sasaran.Kebijakan tidak hanya mempertimbangkan keberlanjutan sumberdaya ikan, melainkan harus juga memberimanfaatsosial ekonomi masa kini dan masa depan. 
Childress MJ, Jurry SH. 2006. Lobsters: Biology, Management, Aquaculture and Fisheries. Phillips BF, editor.Oxford (UK): Blackwell Publishing Ltd. p 78-101.

Creswell JW. 2009. Research Design: Qualitative, Quantitative, and Mixed Methods Approaches. London (UK): Sage Publications. p 203-223.

Herrnkind WF, Butler MJ.1994. Settlement of spiny lobsters, Panulirus argus in Florida: pattern without predictability. Crustaceana, 67 (1):46-64.

Junaidi M, Cokrowati N, Abidin Z. 2010. Aspek reproduksi lobster (Panulirus sp.) di Perairan Teluk Ekas Pulau Lombok [catatan penelitian]. J KELAUTAN. 3(1): 29-35.

[KKP] Kementerian Kelautan dan Perikanan. 2015. Peraturan Menteri Kelautan dan Perikanan Republik Indonesia Nomor 1 /PERMEN-KP/2015 Tentang Penangkapan Lobster (Panulirus spp.), Kepiting (Scylla spp.), dan Rajungan (Portunuspelagicus spp.). Jakarta (ID):KKP. 5 hlm.

[KKP] Kementerian Kelautan dan Perikanan. 2016. Peraturan Menteri Kelautan dan Perikanan Republik Indonesia Nomor 56 /PERMEN-KP/2016 Tentang Larangan Penangkapan dan/atau Pengeluaran Lobster (Panulirus spp.), Kepiting (Scylla spp.), dan Rajungan (Portunuspelagicus spp.). Jakarta (ID):KKP. 8 hlm.

Phillips BF, Smith RM. 2006. Lobsters: Biology, Management, Aquaculture and Fisheries. Phillips BF, editor. Oxford (UK): Blackwell Publishing Ltd. p 359-378.

Phillips BF, Melville-Smith R, Cheng YW. 2003. Estimating the effects of removing Panuliruscygnus pueruli on the fishery stock. Fisheries Research, 65 (2003):89-101.

Purwaka T. 2002. Bunga Rampai Analisis Pengembangan Kapasitas Kelembagaan kelautan Perikanan. Jakarta (ID): FH Unika Atma Jaya. $100 \mathrm{hlm}$.

Suman A, Wudianto, Bambang s, Irianto HE, Badrudin, Amri K. 2014. Potensi dan Tingkat Pemanfaatan Sumberdaya Ikan di Wilayah Pengelolaan Perikanan Republik Indonesia (WPP RI). Jakarta (ID). REF Graphika.

Wij, Hen. 2015. Ekspor anjlok, bukti populasi lobster dan kepiting mulai langka [internet]. [diacu 2017 Oktober 19]. Tersedia dari: https://finance.detik.com/berita-ekonomibisnis/2808765/ekspor-anjlok-bukti-populasi-lobster-dan-kepiting-mulai-langka

Witomo CM, Nurlaili. 2015. Strategi keberlanjutan pengelolaan benih lobster di Perairan Lombok. Jurnal Kebijakan Sosek KP, 5 (1):11-18.

Wiyono ES. 2009. Persepsi nelayan terhadap sumberdaya perikanan. Jurnal Soca, 9 (3):330 - 334. 